\title{
Effects of the New Technology Era on the Economic Growth of Textile and Fashion Market
}

\author{
Smriti Agarwal* \\ Amity University Rajasthan, India \\ *Corresponding author: Smriti Agarwal, Amity University Rajasthan, India \\ submission: 觜May 23, 2018; Published: 漹 July 16, 2018
}

\begin{abstract}
Innovation has been the most important factor for the economic development of the textile and fashion market. In the recent years, the continuous advancement of technology combined with the advanced techniques, together, has been the most important component of the long-term economic growth in any field of fashion and textile. Textile and fashion designing have always needed creativity according to the consumer's interest and thus the market demand, which has been very aptly augmented by the technology era. Having stated that the textile and fashion industry is one of the most significant contributors of our economic growth and development, this study is an attempt to identify the innovative and technological entrepreneurial strategies that are being used in this Industry, to make the products more marketable and profitable.
\end{abstract}

In this paper, the researchers is try to find out why advance technological innovation skills are considered as a major factor in economic growth and develops concern on some of the most important features of innovation in the highly industrialized economies of the Indian Textile and Fashion Market. It also try to find out the impact of technological innovations in the Textile and Fashion Industries and how it is transforming the Fashion business for the growth of the market economy.

Keywords: Textile; Economy; Information communication techniques; Creative economy; Market growth.

\section{Introduction}

Indian textile economy continues to grow upwards and has developed many bright spots in our new creative economy. With the growing number of high-value jobs that pay high wages, fashion is now having a big impact not only in the established fashion centers on the coasts but also in the smaller cities around the country [1]. Fashion and Apparel Industry employees also have a positive impact on regional economies across the country. Many advanced systems and technologies related to Production, Supply, Marketing and Advertisement with effective communication are responsible for the positive growth of the fashion or textile economy [2]. Recently, Information Communication Techniques ICT has helped in increasing entrepreneurship in textile and fashion.

A. ICT has effectively given a direct growth of about $22 \%$ entrepreneurial and creative jobs. In the current hi-tech Textile and Fashion industries jobs like shipping operator, e-merchandising, payments, services feedback collector, accounts, blog maintenance and stock uploading etc.

B. It employs people across occupations - including the designers, computer programmers, lawyers, accountants, copywriters, social media directors and project managers [3].
According to a report by the California Fashion Association, manufacturing is now only a fraction of the modern apparel industry. More sophisticated areas such as market research, brand licensing/ intellectual property rights (IPR), designs, material engineering, hi-tech manufacturing, marketing and finally distribution are an integral part of the new age fashion technology.

\section{GDP growth by advance technology by following eight measure point}

Continue growth of any Industries and high enterpurnship TIE is a most important factor TIE in present time totally based on ICT system of the industries because of all industrial work become digital and will stimulate the growth of new jobs. But it is also an important enabler of innovation and development. Because of all of the $40 \%$ of the business activity of different industries already working on the line.

a) Time Management \&entrepreneur

b) Industries more digital

c) Entrepreneurs think globally 
d) Create new jobs

e) Direct job create

f) Contribution to GDP growth

g) Workforce transformation

h) Business innovation

Different economic system in textile and fashion important for GDP growth. Many economy systems are used for all over marketing all systems are very important for growth and development of the different products in fashion or textile market. Straight of the economy of the market, several economic systems are applied to the overall marketing. However, the state of the economy of the market depends on the following three basic activities:

\section{a. Production of fabrics, \\ b. Conversion into clothing \\ c. Distribution for consumption.}

Although Consumption drives Production and Distribution, the three processes are in many ways, inseparable. The system is very competitive at all stages [4].

\section{Traditional Economic System (TES)}

In the Textile and fashion industries, a Traditional Economic System is very clearly the presence of the strong power looms, natural dyes and printing, weaving, knitting techniques et all which collectively provide the good ratio of the national GDP and entrepreneurship in India. In most parts of India, the traditional textiles business is the most important source of GDP. Products and services are a direct result of traditional beliefs, customs, traditions, religions etc. Vast portions of the world still function under the traditional economic system. Typically these areas tend to be rural areas and in the second and third world countries. Characteristically, waste generation and pollution rate are very low in the TES.

\section{Command}

The most salient feature of command economy is that a large part of the same is controlled by a centralized power, often a central government. The CES usually develops or is useful when the country is in possession of a large quantum of valuable resources, which need to be managed centrally [5]. Although the usual next step to any traditional economy, the CES is by no means, a fairer or better economy and has its share of shortcomings too. From the textile and fashion industry point of view, it generates more GDP due to uniform policy measures, better control so as to enable the central textile ministry to run special programs considering the micro and macroeconomic systems that impact the financial market and thus the textile and fashion market.

\section{Market Economic System (MES)}

A Market Economy is very similar to a free market. The government does not control all activities related to market and supply vital resources, valuable goods or any other major segment of the economy. In this way, organizations run by the people determine how the economy runs, how supply is generated, what demands are necessary, etc. Our government still regulates (or attempts to regulate) fair trade, government programs, moral business, monopolies etc. The advantage to capitalism is you can have an explosive economy that is very well controlled and relatively safe [6]. This would be contrasted with socialism, in which the government (like a command economy) controls and owns the most profitable and vital industries but allows the rest of the market to operate freely; that is, the price is allowed to fluctuate freely based on supply and demand that means high class on economics without boundaries.

\section{Mixed economic system}

A Mixed Economic System (also known as a Dual Economy) is just like it sounds (a combination of economic systems), but it primarily refers to a mixture of a market and command economy. For obvious reasons, a traditional economy does not typically mix well. In the most common types of mixed economies, the market is more or less free of government ownership except for a few key areas. These areas are usually not the resources that a command economy controls.

\section{Textile and fashion industries produces high-fashion, high-value products}

In India today the Fashion and Textile industry has traversed a matured significantly. Pre and post-independence the typical khadi and handloom regime had given way to the power looms, the large textile mills and their finishing and retailing was all directed towards clothing - the basic need of the masses. In the past 70 years, the clothing need has been replaced by the more aesthetic fabrics and apparels to designer wear and ultimately the fashion wear industry. Retail tailoring has been completely replaced by standard outfit and readymade garments [7]. Even the traditional Indian clothes for both men and women have been invaded by the western counterparts. The mindset, preferences, and passion are moving more towards the western wear which consumes lesser fabric but score very high on styling and comfort. These high fashion products naturally command much higher value - although less fabric. The focus has clearly shifted now. Clothes are no longer a cover for the body. Clothes are the statement of status, grooming, and outlook. Hence clothes command a higher value and need a very elaborate and different Production, Marketing and Distribution system.

3.6.1.Fashion industry creates high-paying jobs: While there are still occupations such as sewing machine operators, tailors, and textile machine operators who earn lower wages, today's manufacturing jobs include a number of higher-paying occupations. The focus has shifted from single fabric clothing to multiple fabric confluence. Specific roles in the industry to create lighter and dermatological superior fabrics for various weather conditions are high paying jobs. Textile dying and printing for durability with machine washing is in demand and a lot of textile laboratories are focusing on creating special fabrics as being demanded. Besides, 
simple low-value tailoring is out; high-value boutiques and custommade designs are preferred.

Another significant development leading to high-value textile products and their mass manufacturing is the need for instant purchasing. This has led to the advent of the huge malls and walk-in retail stores where oceans of ready-to-wear clothing ranging from traditional, ethnic, casual, formal, fashion wear, highsociety, fusion and trendy all under one roof need to be displayed, stocked and packaged in standard 5 to 7 range of sizes. Hence the distribution system has also undergone a radical change with the high technology modern economy giving a very positive impetus to the textile and fashion industry today.

\section{Fashion is part of the creative economy}

Many schools and institutions across the country offer fashionrelated programs and prepare students for high-wage jobs in the fashion industry. These programs build skills that are marketable not only in fashion but across industries. For instance, 5 percent of fashion designers worked in the motion picture and video industries in 2013. In addition to preparing students for careers in the fashion industry, many design schools have a significant positive economic impact in their areas. For example, NID, NIFD, IIFT etc. attract more than 10,000 visitors each year.

\section{Conclusion}

Fashion is a sophisticated, thriving industry employing people in a diverse set of occupations across India. Textile and Fashion industries are only one piece of the industry. As the industry has evolved, Textile fashion employers have changed with it, focusing on the high-value parts-R\&D, design, and marketing. Jobs in these fields pay well, and demand for these skills is growing.
High fashion is big business and positive economic impacts from the growth of the fashion industry in their communities. As retailers and fashion designers cluster outside the traditional fashion hubs, this can help facilitate innovation in the fashion industry and benefit other industries in those regions as well.

Today's fashion industry looks very different from even a few years ago. Fashion design schools are arming graduates with the advertising, design, Web, and other skills needed to compete in the rapidly changing global fashion industry. With the growing number of high-paying jobs in the industry, the United States should look to extend its leadership in the fashion world with India being a close second.

\section{References}

1. Autio E, Yli-Renko H (1998) New technology-based firms in small open economies-an analysis based on the finnish experience. Research Policy 26: 973-987.

2. Baumol WJ (1990) Entrepreneurship: productive, unproductive and destructive. The Journal of Political Economy 98(5): 893-921.

3. Cantwell J (2008) Blurred boundaries between firms, and new boundaries within (large multinational) firms: The impact of decentralized networks for innovation. Seoul Journal of Economics 26(1): 1-32.

4. Casson M (2003) The entrepreneur: An economic theory. ( $2^{\text {nd }}$ edn), Edward Elgar, Cheltenham, England.

5. (2016) Nifd: Industry interactions meet. Mumbai, India.

6. Colussy KM (2009) Fashion design on computers. Prentice hall, London, UK.

7. http://www.britishfashioncouncil.com
Creative Commons Attribution 4.0 International License

For possible submissions Click Here
Submit Article

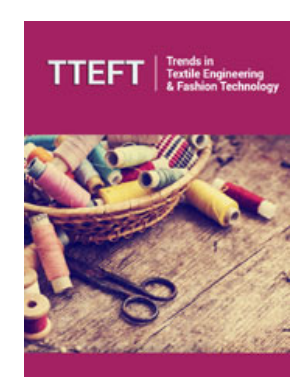

Trends in Textile Engineering \& Fashion Technology

\section{Benefits of Publishing with us}

- High-level peer review and editorial services

- Freely accessible online immediately upon publication

- Authors retain the copyright to their work

- Licensing it under a Creative Commons license

- Visibility through different online platforms 